\title{
GENETIC BEHAVIOR OF YIELD AND FIBER TRAITS IN SOME BARBADENSE COTTON CROSSES
}

\author{
ORABI, M.H.M. , EMAN M.R. SALEH AND SAMIA E. ALI
}

\author{
Cotton Research Institute, ARC, Giza, Egypt
}

(Manuscript received 4 October 2017)

\begin{abstract}
$\mathrm{T}$ his investigation was carried out at Sakha Experimental Station, Agricultural Research Center during four seasons 2013, 2014, 2015 and 2016. Five populations $\left(P_{1}, P_{2}, F_{1}, F_{2}\right.$ and $F_{3}$ ) for the four barbadense cotton crosses namely (Uzbekstan1 x C.B 58), (TNB x C.B 58), (BBB x C.B 58) and (Giza 94 x Giza 45) were used in this investigation to study the genetic behavior of yield and its components and fiber traits. The aim of the present investigation was to study heterosis, inbreeding depression and type of gene action in four intra-specific crosses to obtain additional information about some genetic parameters to help the breeder to select effective breeding methods. The results showed that the potence ratio estimates indicated over dominance for seed cotton and lint yield/plant, boll weight, lint percentage and number of bolls/plant, while the quality traits exhibited partial dominance. Highly significant positive heterotic effects relative to mid-parent and better parent were obtained for seed cotton yield, lint cotton yield and number of bolls/plant, while it was for lint percentage. The inbreeding depression effects were highly significant for number of bolls/plant, seed cotton yield and lint cotton yield. Highly significant values of additive and dominance were found for seed cotton yield, lint cotton yield and number of bolls/plant. Dominance effects for Micronaire value and fiber length were of greater magnitude than additive effects. Highly significant epistasis values were found for additive $\mathrm{x}$ additive and dominance $\mathrm{x}$ dominance with complementary action with non additive effect. High broad sense heritability values were calculated for all studied traits, while narrow sense heritability values were of low values for seed cotton and lint cotton yield. on the other hand the fiber quality traits exhibited high values in three crosses as well as the heritabilities of regression
\end{abstract}

\section{INTRODUCTION}

Cotton is considered one from the most important cash crops in Egypt hence great efforts have been devoted to increase the yield, its components and fiber properties through breeding programs which depends on the knowledge concerning multiple factors such as heterosis, inbreeding depression and the nature of the interactions of gene controlling the quantitative traits. Many authors studied these factors. El-Desouqi et al., (2000) pointed out to the occurrence of positive and significant heterosis relative to mid-parents for boll weight, seed index in two crosses 
and lint yield /plant in the first cross. Meanwhile, significant positive heterosis relative to better parent was detected for seed index in the second cross. On the other hand, they found significant positive inbreeding depression in $F_{2}$ and $F_{3}$ generations for boll weight, seed index and lint index in the second cross. The additive gene effects were significantly positive for seed cotton yield /plant, lint yield /plant and boll weight in the two crosses. Whereas, dominance gene effects were significant for most studied traits in cross I. Epistatic components were greater in magnitude than additive or dominance components for most studied traits. El-Disouqi and Zeina (2001) reported that the roles of non-allelic interaction were governing most of studied traits in two crosses. The additive gene effects were significantly positive or negative for all studied traits except seed cotton yield / plant in cross I and dominance gene effects were important in the inheritance of most studied traits in both crosses and were relatively high in magnitude compared with additive effects in all variables. They also added that, heritability values in narrow sense were low (23.22\%) for seed cotton yield /plant in cross I. Zeina (2002) stated that additive genetic variances accounted for the major proportion of phenotypic variance for all traits studied. He also added that, this resulted confirm the high heritabilities in narrow sense for all studied traits, suggesting the high values of additive genetic variances and small values of environmental variances in these respect. Soliman (2003) reported highly significant positive heterosis relative to mid and better-parents for seed cotton yield /plant, lint yield /plant, fiber strength and fiber length in all crosses. Also, highly significant positive inbreeding depression values were detected in $F_{2}$ and $F_{3}$ generations for most studied traits. All types of gene action effects were significant for yield, its components and fiber properties. While, dominance and epistatic effects were higher in magnitude than additive in some traits. Abou El-Yazied et al., (2008) found highly significant positive heterosis relative to mid-parent for most studied traits in the two crosses. In addition, heterosis relative to the better parent was significantly positive for boll weight, lint yield/plant, lint percentage and $2.5 \%$ span length in cross I and for all studied traits in cross II except number of bolls/plant and fiber strength. Highly significant positive inbreeding depression values were recorded in $F_{2}$ and $F_{3}$ for boll weight, seed cotton yield / plant lint yield/plant and 2.5\% span length in the two crosses as well as, lint percentage, number of bolls/plant and fiber fineness in cross I and seed index in cross II. Over dominance appeared to be controlling most studied traits in $F_{1}$ hybrids and $F_{2}$ generations in the two crosses and the other remaining traits were controlled by partial dominance. 


\section{MATERIALS AND METHODS}

This study was carried out at Sakha Experimental Station, Agricultural Research Center during the four growing seasons 2013, 2014, 2015 and 2016. Crossing is used between Uzbekstan1 with C.B 58, TNB with C.B 58, BBB with C.B 58, and Giza 94 with Giza 45.

In (2013), the parental genotypes were crossed to obtain $F_{1}$ seeds. In the second season (2014), the hybrid seeds of the four crosses were sown to give the $F_{1}$ plants. These plants were selfed to produce $F_{2}$ seeds. Moreover, the same crosses were made to have enough $F_{1}$ seeds. The new hybrid seeds and part of seeds obtained from $F_{1}$ selfed plants ( $F_{2}$ seeds) were kept to the final experiment. In (2015) the $F_{1}$ and $F_{2}$ plants were selfed to produce $F_{2}$ and $F_{3}$ seeds, respectively. In the fourth season (2016) the obtained seeds of the five populations ( $P_{1}, P_{2}, F_{1}, F_{2}$ and $F_{3}$ ) of the four crosses were evaluated using randomized complete blocks design with three replications. Each non-segregating generation $\left(P_{1}, P_{2}\right.$ and $\left.F_{1}\right)$ was consisted of five rows, while $F_{2}$ and $F_{3}$ contained 30 Rows. Each row was $4.2 \mathrm{~m}$ in length, and 60 $\mathrm{cm}$ in width. Hills were spaced $70 \mathrm{~cm}$ within row and plants were thinned to one plant / hill. All the agronomic practices were done according to the ordinary cotton culture. Data and measurements were recorded for nine characters on individual guarded plants, (30 for each of $P_{1}, P_{2}$ and $F_{1}$ and 160 for each of $F_{2}$ and $F_{3}$ ), to study performance of the nine following traits:

I- Yield and its components including boll weight, number of bolls /plant, seed cotton yield/plant, lint cotton yield / plant, lint percentage.

II- $\quad$ Fiber properties including fiber fineness as Micronaire reading, fiber strength as Pressely index and fiber length (2.5\% span length in $\mathrm{mm}$ ).

\section{Statistical and Genetic Analysis:}

\section{1- Estimates of gene effects:}

The analysis of variance of the five basic populations $\left(P_{1}, P_{2}, F_{1}, F_{2}\right.$, and $\left.F_{3}\right)$ was statistically analyzed using (RCBD) analysis of variance. The parameters of the genetic model ( $m, d, h$, i and I) were computed according to Jinks and Jones (1958) as follows:

$[\mathrm{m}]=\mathrm{F}_{2}$ mean performance S.E. $(\mathrm{m})=\left(\mathrm{V}_{\mathrm{m}}\right)^{1 / 2}$

$[d]=$ additive effect $=1 / 2\left(P_{1}-P_{2}\right)$ S.E. $(d)=\left(V_{d}\right)^{1 / 2}$

$[h]=$ dominance effects $=1 / 6\left(4 F_{1}+12 F_{2}-16 F_{3}\right) S . E .(h)=\left(V_{h}\right)^{1 / 2}$

$[i]=$ additive $x$ additive type of gene interaction $=P_{1}-F_{2}+1 / 2\left(P_{1}-P_{2}+h\right)$ S.E.

(i) $=\left(V_{i}\right)^{1 / 2}$

[I] = dominance $x$ dominance type of gene interaction $=1 / 3\left(16 F_{3}-24 F_{2}+8 F_{3}\right)$

S.E. $(I)=\left(V_{1}\right)^{1 / 2}$ 


\section{2- Heritability estimates:}

a. Heritability in broad sense $\left(\mathrm{h}^{2} \mathrm{~b}\right): \mathrm{h}^{2} \mathrm{~b}=\frac{\mathrm{V} F_{2}-\mathrm{V} E}{\mathrm{~V} F_{2}}=\frac{1 / 2 D+1 / 4 H}{1 / 2 D+1 / 4 H+E} \times 100$

b. Heritability in narrow sense $\left(\mathrm{h}^{2} \mathrm{n}\right): \mathrm{h}^{2} \mathrm{n}=\frac{1 / 2 D}{1 / 2 D+1 / 4 H+E} \times 100$ (Allard, 1960)

Where:

$V_{E}$ is the environmental variance calculated as the average variance of $P_{1}, P_{2}$ and $F_{1}$

$\mathrm{VF}_{2}$ is the total phenotypic variance in $\mathrm{F}_{2}$.

c. Parent-offspring regression, i.e. regression of $F_{3}$ line means on their corresponding $F_{2}$ plant values (b). $\mathrm{b}=\frac{\mathrm{C} \text { ov } \cdot F_{2} / F 3}{V F_{2}}=\frac{1 / 2 D+1 / 8 H}{1 / 2 D+1 / 4 H+E}$

\section{3- Expected genetic advance under selection:}

Genetic advance was calculated according to Johanson et al., (1955) as follows:

$$
\text { G.S. }=K \times Q_{p} \times h^{2} n
$$

Where: G.S = expected genetic advance from selection

$K=$ selection differential with a value of 2.06 under $5 \%$ selection intensity.

$\mathrm{Q}_{p}=$ phenotypic standard deviation

$h^{2} n=$ Heritability in narrow sense.

Expected genetic advance as percentage: G.S\% $=\frac{\mathrm{G} . \mathrm{S}}{\overline{\mathrm{F}_{2}}} \times 100$

Means and variances were computed, and then the following estimates were calculated:

Heterosis was calculated as percent increase $(+)$ or decrease $(-)$ over mid-parents $\left(\mathrm{H}_{\mathrm{MP}} \%\right)$ and better parents ( $\left.\mathrm{H}_{\mathrm{B} . \mathrm{P}} \%\right)$. The heterosis measurements were calculated by the following equations:

$$
\begin{aligned}
& \text { Heterosis over the mid-parents (H.M.P \%) }=\frac{\overline{\mathrm{F}}_{1}-\overline{\mathrm{MP}}}{\overline{\mathrm{MP}}} \times 100 \\
& \text { Heterosis over the better-parent (H.B.P \%) }=\frac{\overline{\mathrm{F}_{1}-\overline{\mathrm{B} . \mathrm{P}}}}{\overline{\mathrm{B} . \mathrm{P}}} \times 100
\end{aligned}
$$

Inbreeding depression from $F_{1}$ to $F_{2}\left(\right.$ I.D. $\left.F_{2} \%\right)=\frac{\bar{F}_{1}-\bar{F}_{2}}{\bar{F}_{1}} \times 100$

Inbreeding depression from $F_{1}$ to $F_{3}\left(\right.$ I.D. $\left.F_{3} \%\right)=\frac{\overline{\mathrm{F}}_{1}-\overline{\mathrm{F}}_{3}}{\overline{\mathrm{F}}_{1}} \times 100$

Nature and degree of dominance were determined by means of potence ratio method outlined by Smith (1952), which can be defined as follows: 


$$
\begin{aligned}
\text { Potence ratio in } F_{1}\left(P . R . F_{1}\right) & =\frac{\bar{F}_{1}-\bar{M} . P}{1 / 2\left(\overline{\mathrm{P}}_{1}-\overline{\mathrm{P}}_{2}\right)} \\
\text { Potence ratio in } \mathrm{F}_{2}\left(\mathrm{P} . \mathrm{R} . \mathrm{F}_{2}\right) & =\frac{2\left(\overline{\mathrm{F}}_{2}-\overline{\mathrm{M} . \mathrm{P}}\right)}{1 / 2\left(\overline{\mathrm{P}}_{1}-\overline{\mathrm{P}}_{2}\right)}
\end{aligned}
$$

The population means and variances were used to compute the scaling tests $C$ and $D$ and to estimate the type of gene effects according to Mather and Jinks (1982).

Estimation of both scaling tests and gene effects were tested for significance from zero using student's $t$ - test .Scaling test for independence of genetic from environmental effects variance of non-segregating generations i.e., $\mathrm{P}_{1}, \mathrm{P}_{2}$ and $\mathrm{F}_{1}$ ratio, if proves significance there is genotypes $\mathrm{x}$ environment interaction

$$
\mathrm{F}=V P_{1} / V P_{2}, V P 1 / V F_{1} \text { and } V P_{2} / V F_{1}
$$

\section{Where}

$\bar{F}$ is the mean of $\mathrm{F}_{1}$ cross.

$\bar{M} P$ is the mean of the parents.

$\bar{B} P$ is the mean of the better parent.

\section{RESULTS AND DISCUSSION}

The estimation of variances of the two parents and $\mathrm{F}_{1}$ were computed to clear the genotype-environment interaction. The data in (Table 1) showed scaling test genotype-environment interaction for eight traits of four Egyptian cotton crosses.

The data in (Table 1) showed that the F-ratios between $\mathrm{VP}_{1} / \mathrm{VP}_{2}$ were insignificant for all studied traits in the four crosses which indicated that the interaction between the parents were insignificant, while it was significant for seed cotton yield in cross II. The ratio of $\mathrm{VP}_{1} / \mathrm{VF}_{1}$ and $\mathrm{VP}_{2} / \mathrm{VF}_{1}$ were highly significant for boll weight, number of bolls, seed cotton yield, lint cotton yield and lint percentage in cross I, also it were highly significant for seed and lint cotton yield in cross III. These results indicated significant interaction in these traits.

The five generations of the four crosses included their parents, $F_{1}{ }^{\prime} S_{1}, F_{2}{ }^{\prime} S$ and $\mathrm{F}_{3}$ 'S generations and their performance were presented in (Table 2). The results showed significant differences between the means of the two parents for number of bolls /plant, seed cotton yield and lint cotton yield in the four crosses. 
Table 1 . Scaling test for genotype $\mathrm{x}$ environment interaction for eight studied characters in four Egyptian cotton crosses

\begin{tabular}{|c|c|c|c|c|c|c|c|c|}
\hline \multirow[t]{2}{*}{ Parameters } & \multicolumn{8}{|c|}{ Characters } \\
\hline & B.W & No.Boll & S.C.Y & L.C.Y & $L \%$ & Mic & F.S & F.L \\
\hline \multicolumn{9}{|c|}{ Cross I } \\
\hline$F=V P_{1} / V P_{2}$ & 0.423 & 0.693 & 0.911 & 1.217 & 0.179 & 1.187 & 1.292 & 1.185 \\
\hline$F=V P_{1} / V F_{1}$ & 1.195 & $2.133^{*}$ & $2.702^{* *}$ & $2.298^{* *}$ & 1.031 & 0.440 & 0.532 & 0.750 \\
\hline$F=V_{2} / V_{1}$ & $2.826^{* *}$ & $3.077^{* *}$ & $2.965^{* *}$ & 1.888 & $5.746 * *$ & 0.371 & 0.412 & 0.633 \\
\hline \multicolumn{9}{|c|}{ Cross II } \\
\hline$F=V P_{1} / V_{2}$ & 0.658 & 0.707 & 2.013* & 1.154 & 0.236 & 0.957 & 0.982 & 1.187 \\
\hline$F=V P_{1} / V F_{1}$ & 0.807 & 1.234 & $2.369 *$ & 1.624 & 0.772 & 0.418 & 0.460 & 0.473 \\
\hline$F=V P_{2} / V F_{1}$ & 1.227 & 1.744 & 1.177 & 1.408 & $3.266 * *$ & 0.437 & 0.469 & 0.399 \\
\hline \multicolumn{9}{|c|}{ Cross III } \\
\hline$F=V P_{1} / V_{2}$ & 0.258 & 0.808 & 1.288 & 1.000 & 0.682 & 1.856 & 1.720 & 1.441 \\
\hline$F=V P_{1} / V_{1}$ & 0.192 & 1.485 & $2.569 * *$ & $2.590 * *$ & 1.547 & 0.349 & 0.361 & 0.356 \\
\hline$F=V P_{2} / V F_{1}$ & 0.744 & 1.839 & 1.994* & $2.590 * *$ & $2.268^{*}$ & 0.188 & 0.210 & 0.247 \\
\hline \multicolumn{9}{|c|}{ Cross IV } \\
\hline$F=V P_{1} / V P_{2}$ & 1.473 & 1.033 & 1.593 & 1.675 & 1.501 & 1.489 & 1.142 & 0.562 \\
\hline$F=V P_{1} / V F_{1}$ & 0.350 & 0.892 & 1.721 & $2.248^{*}$ & 1.873 & 0.627 & 0.529 & 0.524 \\
\hline$F=V P_{2} / V F_{1}$ & 0.238 & 0.864 & 1.081 & 1.342 & 1.248 & 0.421 & 0.463 & 0.932 \\
\hline
\end{tabular}

$*$ significant and $* *$ high significant at $5 \%$ and $1 \%$ respectively.

Regarding boll weight, the differences between two the parents of these crosses were not clear, while for lint percentage the differences between the two parents of these crosses were clear only in cross IV and cross I. Concerning the quality traits (micronaire value, fiber length and fiber strength), the differences between their parents were not clear. The performances of the $F_{1}$ 'S were of higher values for number of bolls per plant, seed and lint cotton yield per plant and lint percentage than its parents and the $F_{2}{ }^{\prime} S$ and $F_{3}{ }^{\prime} S$ in four crosses. These results reflected the presence of heterotic effect and higher dominance gene controlling of these traits. The $F_{1}$ 'S of the two crosses III and IV were the best $F_{1}{ }^{\prime} S$.

The highest means of $F_{2}$ 'S were exhibited in cross III and cross IV. These results may be attributed to its first parents which were varieties BBB for cross III and Giza 94 for cross IV. The data of potence ratio, heterosis, inbreeding depression, heritability and genetic advance of the four crosses are given in (Table 3). With respect to potence ratio, the results cleared the presence of over dominance for yield and yield components in $F_{1}$ hybrids in the four crosses except for lint percentage in cross IV.

No dominance effects were obtained in $F_{1}$ for quality traits exhibited no dominance. Concerning these results, if the parental value and $F_{1}$ or $F_{2}$ generally were nearly equal then the relatively small error in estimation could magnify the potence values (Petr and Fery 1966), also could be obtained from the failure of parents of equal phenotypic values to carry the same dominant and duplication genes in different genomes may underestimate or over estimate the potence ratio which could exist if the genes were acting in diploid state. Over dominance for yield components were obtained by El-Hoseiny et al.,(2013). 
Table 2. Mean and their standard errors of five populations for eight characters.

\begin{tabular}{|c|c|c|c|c|c|c|c|c|c|}
\hline & & B.W & No.Boll & S.C.Y & L.C.Y & $L \%$ & Mic & F.S & F.L \\
\hline \multirow{5}{*}{ 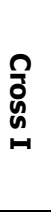 } & $\mathbf{P}_{\mathbf{1}}$ & $3.22 \pm 0.03 * *$ & $53.28 \pm 1.29 * *$ & $171.11 \pm 4.02 * *$ & $65.78 \pm 1.51^{* *}$ & $38.46 \pm 0.10 * *$ & $4.19 \pm 0.02^{* *}$ & $10.20 \pm 0.02 * *$ & $33.79 \pm 0.08^{* *}$ \\
\hline & $\mathbf{P}_{\mathbf{2}}$ & $3.22 \pm 0.04 * *$ & $48.56 \pm 1.18^{* *}$ & $155.89 \pm 3.54 * *$ & $61.58 \pm 1.39 * *$ & $39.52 \pm 0.07 * *$ & $4.07 \pm 0.06 * *$ & $10.21 \pm 0.02 * *$ & $33.36 \pm 0.08^{* *}$ \\
\hline & $\mathbf{F}_{\mathbf{1}}$ & $3.45 \pm 0.02 * *$ & $70.16 \pm 1.49 * *$ & $242.34 \pm 5.52 * *$ & $100.08 \pm 2.28^{* *}$ & $41.30 \pm 0.12 * *$ & $4.13 \pm 0.02 * *$ & $10.21 \pm 0.02 * *$ & $33.58 \pm 0.05^{* *}$ \\
\hline & $\mathbf{F}_{\mathbf{2}}$ & $3.20 \pm 0.02 * *$ & $57.77 \pm 1.83^{* *}$ & $167.89 \pm 5.41^{* *}$ & $69.09 \pm 2.29 * *$ & $41.01 \pm 0.10^{* *}$ & $3.92 \pm 0.04 * *$ & $10.27 \pm 0.05^{* *}$ & $34.15 \pm 0.17 * *$ \\
\hline & $\mathbf{F}_{\mathbf{3}}$ & $3.10 \pm 0.02 * *$ & $56.44 \pm 2.63 * *$ & $163.20 \pm 7.72^{* *}$ & $63.60 \pm 3.02 * *$ & $38.98 \pm 0.16^{* *}$ & $4.28 \pm 0.06 * *$ & $10.34 \pm 0.04 * *$ & $34.00 \pm 0.08^{* *}$ \\
\hline \multirow{5}{*}{ 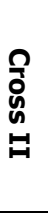 } & $\mathbf{P}_{1}$ & $3.14 \pm 0.03 * *$ & $53.59 \pm 1.29 * *$ & $167.79 \pm 3.51^{* *}$ & $65.56 \pm 1.36^{* *}$ & $39.08 \pm 0.08^{* *}$ & $3.85 \pm 0.03 * *$ & $10.43 \pm 0.02 * *$ & $34.58 \pm 0.12 * *$ \\
\hline & $\mathbf{P}_{\mathbf{2}}$ & $3.22 \pm 0.04 * *$ & $48.56 \pm 1.18^{* *}$ & $155.89 \pm 3.54 * *$ & $61.58 \pm 1.39 * *$ & $39.52 \pm 0.07 * *$ & $4.07 \pm 0.06 * *$ & $10.21 \pm 0.02 * *$ & $33.36 \pm 0.08^{* *}$ \\
\hline & $\mathbf{F}_{\mathbf{1}}$ & $3.15 \pm 0.04 * *$ & $68.59 \pm 1.88^{* *}$ & $215.17 \pm 5.17 * *$ & $86.59 \pm 2.10^{* *}$ & $40.24 \pm 0.11^{* *}$ & $3.96 \pm 0.03^{* *}$ & $10.32 \pm 0.02 * *$ & $33.97 \pm 0.08^{* *}$ \\
\hline & $\mathbf{F}_{\mathbf{2}}$ & $3.03 \pm 0.04 * *$ & $50.27 \pm 2.10^{* *}$ & $148.72 \pm 6.20 * *$ & $58.54 \pm 2.10^{* *}$ & $39.45 \pm 0.20 * *$ & $3.89 \pm 0.03 * *$ & $10.14 \pm 0.03^{* *}$ & $33.37 \pm 0.09 * *$ \\
\hline & $\mathbf{F}_{3}$ & $2.90 \pm 0.04 * *$ & $48.64 \pm 3.33 * *$ & $139.08 \pm 9.59 * *$ & $50.95 \pm 3.64 * *$ & $36.46 \pm 0.23 * *$ & $4.60 \pm 0.05^{* *}$ & $10.01 \pm 0.05^{* *}$ & $34.01 \pm 0.11^{* *}$ \\
\hline \multirow{5}{*}{ 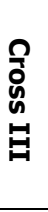 } & $\mathbf{P}_{\mathbf{1}}$ & $3.23 \pm 0.02 * *$ & $61.37 \pm 1.42^{* *}$ & $198.15 \pm 4.64 * *$ & $78.83 \pm 1.89 * *$ & $39.77 \pm 0.10^{* *}$ & $4.33 \pm 0.03 * *$ & $10.21 \pm 0.02 * *$ & $34.61 \pm 0.07 * *$ \\
\hline & $\mathbf{P}_{\mathbf{2}}$ & $3.22 \pm 0.04 * *$ & $48.56 \pm 1.18^{* *}$ & $155.89 \pm 3.54 * *$ & $61.58 \pm 1.39 * *$ & $39.52 \pm 0.10^{* *}$ & $4.07 \pm 0.04 * *$ & $10.13 \pm 0.02 * *$ & $33.36 \pm 0.07 * *$ \\
\hline & $\mathbf{F}_{\mathbf{1}}$ & $3.23 \pm 0.05^{* *}$ & $102.69 \pm 2.38^{* *}$ & $330.86 \pm 7.73 * *$ & $137.99 \pm 3.20 * *$ & $41.72 \pm 0.12 * *$ & $4.20 \pm 0.02 * *$ & $10.17 \pm 0.01 * *$ & $33.98 \pm 0.05^{* *}$ \\
\hline & $\mathbf{F}_{2}$ & $3.31 \pm 0.02 * *$ & $84.54 \pm 2.52 * *$ & $279.30 \pm 8.36 * *$ & $111.24 \pm 3.25^{* *}$ & $39.95 \pm 0.14^{* *}$ & $4.21 \pm 0.03^{* *}$ & $10.09 \pm 0.03 * *$ & $34.27 \pm 0.04 * *$ \\
\hline & $\mathbf{F}_{3}$ & $3.08 \pm 0.02 * *$ & $69.91 \pm 2.12^{* *}$ & $213.57 \pm 6.33 * *$ & $82.50 \pm 2.48 * *$ & $38.60 \pm 0.14 * *$ & $4.00 \pm 0.03 * *$ & $10.38 \pm 0.04 * *$ & $34.23 \pm 0.06^{* *}$ \\
\hline \multirow{5}{*}{ 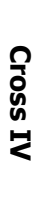 } & $\mathbf{P}_{\mathbf{1}}$ & $3.21 \pm 0.02 * *$ & $85.80 \pm 9.26 * *$ & $275.76 \pm 3.86^{* *}$ & $110.62 \pm 1.62 * *$ & $40.11 \pm 0.12^{* *}$ & $3.97 \pm 0.05^{* *}$ & $10.51 \pm 0.03 * *$ & $36.45 \pm 0.08^{* *}$ \\
\hline & $\mathbf{P}_{\mathbf{2}}$ & $2.93 \pm 0.02 * *$ & $54.15 \pm 7.36^{* *}$ & $158.22 \pm 3.61 * *$ & $57.26 \pm 1.33 * *$ & $36.18 \pm 0.08^{* *}$ & $3.64 \pm 0.03 * *$ & $10.31 \pm 0.02 * *$ & $34.34 \pm 0.06 * *$ \\
\hline & $\mathbf{F}_{\mathbf{1}}$ & $3.26 \pm 0.03 * *$ & $101.73 \pm 10.09 * *$ & $331.11 \pm 5.31 * *$ & $126.65 \pm 2.05^{* *}$ & $38.25 \pm 0.08 * *$ & $3.81 \pm 0.03 * *$ & $10.41 \pm 0.02 * *$ & $35.39 \pm 0.06 * *$ \\
\hline & $\mathbf{F}_{2}$ & $3.11 \pm 0.02 * *$ & $63.93 \pm 7.10 * *$ & $197.59 \pm 4.53^{* *}$ & $74.21 \pm 1.63^{* *}$ & $37.68 \pm 0.19 * *$ & $3.60 \pm 0.13^{* *}$ & $10.49 \pm 0.01 * *$ & $34.96 \pm 0.05^{* *}$ \\
\hline & $\mathbf{F}_{3}$ & $3.50 \pm 0.02 * *$ & $44.95 \pm 6.70 * *$ & $156.66 \pm 5.61^{* *}$ & $62.13 \pm 2.23 * *$ & $39.70 \pm 0.15^{* *}$ & $4.34 \pm 0.08 * *$ & $10.92 \pm 0.02 * *$ & $35.77 \pm 0.07 * *$ \\
\hline
\end{tabular}

* significant and $* *$ high significant at $5 \%$ and $1 \%$ respectively. 
Regarding the potency ratio in $F_{2}$, the results in (Table 3 ) indicated over dominance for all traits in cross I and cross II and yield components in cross III, these agreed with those obtained by Abou El-Yazied et al. (2008) who stated that over dominance controlled inheritance of seed cotton yield /plant and lint cotton yield / plant.

Table 3. Genetic parameters for four Egyptian cotton crosses

\begin{tabular}{|c|c|c|c|c|c|c|c|c|c|c|c|}
\hline \multirow{2}{*}{ Trait } & \multicolumn{2}{|c|}{ Potence ratio } & \multicolumn{2}{|c|}{ Heterosis } & \multicolumn{2}{|c|}{$\begin{array}{l}\text { Inbreeding } \\
\text { depression }\end{array}$} & \multicolumn{3}{|c|}{ Heritability\% } & \multicolumn{2}{|c|}{ Genetic advance } \\
\hline & $F_{1}$ & $F_{2}$ & M-P & B-P & $\mathbf{F}_{2}$ & $F_{3}$ & B.S & N.S & b\% & Value & $\%$ \\
\hline \multicolumn{12}{|c|}{ Cross I } \\
\hline B.W & 4.82 & -3.00 & 5.91 & 4.63 & 7.32 & 10.21 & 66.13 & 42.44 & 38.07 & 1.96 & 61.12 \\
\hline No.Boll & 8.16 & 5.80 & 37.79 & 31.69 & 17.66 & 19.55 & 90.11 & 2.19 & 4.67 & 8.23 & 14.24 \\
\hline S.C.Y & 10.36 & 1.15 & 48.22 & 41.63 & 30.72 & 32.66 & 87.38 & 0.64 & 1.89 & 7.13 & 4.24 \\
\hline L.C.Y & 17.34 & 5.15 & 57.16 & 52.14 & 30.97 & 36.46 & 88.74 & 1.10 & 5.25 & 5.19 & 7.52 \\
\hline$L \%$ & 4.36 & 7.63 & 5.93 & 4.51 & 0.71 & 5.64 & 80.53 & 47.77 & 49.37 & 9.49 & 23.14 \\
\hline Mic & 0.00 & -7.13 & 0.00 & 1.47 & 5.18 & -3.62 & 80.76 & 42.56 & 53.86 & 3.18 & 81.18 \\
\hline F.S & 0.00 & 81.00 & 0.00 & -0.02 & -0.7 & -1.35 & 96.91 & 0.00 & 65.37 & -0.72 & -6.98 \\
\hline F.L & 0.00 & 5.24 & 0.00 & -0.65 & -1.70 & -1.26 & 96.83 & 42.17 & 42.32 & 14.94 & 43.74 \\
\hline \multicolumn{12}{|c|}{ Cross II } \\
\hline B.W & -0.81 & -7.82 & -0.97 & 2.15 & 3.77 & 8.044 & 81.42 & 0.00 & 27.79 & -7.57 & -249.79 \\
\hline No.Boll & 6.97 & -0.64 & 34.29 & 27.99 & 26.72 & 29.08 & 90.66 & 1.88 & 4.67 & 8.11 & 16.13 \\
\hline S.C.Y & 8.96 & -4.41 & 32.95 & 28.25 & 30.88 & 35.36 & 91.60 & 0.57 & 2.19 & 7.32 & 4.92 \\
\hline L.C.Y & 11.57 & -5.06 & 36.20 & 32.07 & 32.39 & 41.16 & 91.02 & 1.20 & 6.34 & 5.91 & 10.09 \\
\hline$L \%$ & 4.32 & 1.36 & 2.40 & 1.84 & 1.977 & 9.402 & 95.78 & 0.00 & 41.56 & -27.05 & -68.57 \\
\hline Mic & 0.00 & -1.22 & 0.00 & 2.86 & 1.689 & -16.21 & 70.46 & 54.38 & 48.77 & 3.50 & 89.91 \\
\hline F.S & 0.00 & -3.19 & 0.00 & -1.07 & 1.728 & 2.958 & 90.38 & 80.20 & 61.43 & 4.94 & 48.76 \\
\hline F.L & 0.00 & -1.96 & 0.00 & -1.77 & 1.766 & -0.126 & 79.71 & 54.38 & 60.50 & 9.97 & 29.89 \\
\hline \multicolumn{12}{|c|}{ Cross III } \\
\hline B.W & 1.27 & 34.60 & 0.20 & 0.04 & -2.48 & 4.81 & 56.33 & 5.92 & 39.99 & 0.29 & 8.78 \\
\hline No.Boll & 7.46 & 9.24 & 86.84 & 67.35 & 17.68 & 31.92 & 91.07 & 3.40 & 8.97 & 17.67 & 20.90 \\
\hline S.C.Y & 7.28 & 9.68 & 86.91 & 66.98 & 15.59 & 35.45 & 91.61 & 1.11 & 3.67 & 19.18 & 6.87 \\
\hline L.C.Y & 7.86 & 9.52 & 96.54 & 75.04 & 19.38 & 40.21 & 90.66 & 2.66 & 8.69 & 17.81 & 16.01 \\
\hline$L \%$ & 16.15 & 4.68 & 5.23 & 4.89 & 4.25 & 7.48 & 89.36 & 15.58 & 41.17 & 4.59 & 11.48 \\
\hline Mic & 0.00 & 0.23 & 0.00 & 3.15 & -0.35 & 4.72 & 73.84 & 70.83 & 58.20 & 3.67 & 87.02 \\
\hline F.S & -0.08 & -4.13 & -0.03 & -0.42 & 0.78 & -2.07 & 89.75 & 63.53 & 47.14 & 3.46 & 34.33 \\
\hline F.L & 0.00 & 0.93 & 0.00 & -1.81 & -0.85 & -0.73 & 44.71 & 72.51 & 73.67 & 5.47 & 15.95 \\
\hline \multicolumn{12}{|c|}{ Cross IV } \\
\hline B.W & 1.31 & 0.57 & 6.10 & 1.36 & 4.49 & -7.49 & 60.31 & 79.60 & 31.76 & 2.79 & 89.55 \\
\hline No.Boll & 2.01 & -0.77 & 45.38 & 18.57 & 37.16 & 55.82 & 86.17 & 14.45 & 23.59 & 43.31 & 67.76 \\
\hline S.C.Y & 1.94 & -0.66 & 52.59 & 20.07 & 40.32 & 52.69 & 82.92 & 4.98 & 8.47 & 46.45 & 23.51 \\
\hline L.C.Y & 1.60 & -0.77 & 50.88 & 14.49 & 41.86 & 50.94 & 79.86 & 13.47 & 18.76 & 44.47 & 60.40 \\
\hline$L \%$ & -0.23 & 0.46 & -1.17 & -6.00 & -2.39 & -5.31 & 95.65 & 79.82 & 56.03 & 21.08 & 54.60 \\
\hline Mic & 0.00 & -2.45 & 0.00 & 4.58 & 5.36 & -14.13 & 70.79 & 69.32 & 43.18 & 4.01 & 111.35 \\
\hline F.S & 0.02 & 1.50 & 0.02 & -0.94 & -0.70 & -4.90 & 56.26 & 77.61 & 42.57 & 21.89 & 21.89 \\
\hline F.L & -0.01 & -0.83 & -0.01 & -2.90 & 1.23 & -1.06 & 55.51 & 78.68 & 45.13 & 7.26 & 20.78 \\
\hline
\end{tabular}

On the other hand, partial dominance controlled the quality traits in cross III and all traits in cross IV except micronaire value and fiber strength. 
The values of heterosis over mid-parent and better parent were presented in (Table 3). The data showed significant positive heterotic mid-parents and better parent effects for number of bolls /plant, seed cotton yield/plant and lint cotton yield/plant in the four studied crosses, while boll weight and lint percentage existed with small amount values. These results were in harmony with those obtained by AbdEl-Haleem et al., (2010). Moreover, that quality traits did not exhibit heterotic effect. This finding was in disagreement with those obtained by Abdalla ( 2007).

Regarding inbreeding depression, the data in (Table 3) showed significant positive inbreeding depression in $F_{2}$ and $F_{3}$ for number of bolls /plant, seed cotton yield/plant and lint cotton yield/plant in the four studied crosses. These results suggested the accumulation of additive gene effects, which in turn increases the mean expression of these characters. These results were in agreement with those obtained by Abou El-Yazied et al.,(2008).

Lint percentage exhibited positive small amount of inbreeding depression in $\mathrm{F}_{2}$ of all crosses except for cross IV had negative small amount, while the inbreeding depression of lint percentage in $F_{3}$ were positively by moderate except for cross IV. The inbreeding depression for micronaire values in $F_{2}$ were positively moderate in crosses I and IV, while in $\mathrm{F}_{3}$ it was positive and moderate in crosses III. On the other hand, the inbreeding depression for crosses I, II and IV were exhibited negative significant values.

Concerning heritability estimates in broad and narrow senses as well as index of regression $F_{2}$ on $F_{3}$ generations, (Table 3 ) showed relatively highly values of broad sense heritability for all studied traits in the four studied crosses except fiber strength in cross III which was of moderate value. Narrow sense heritability were of highly values for micronaire reading, pressely index and fiber length in crosses II, III and IV. The boll weight exhibited high narrow sense in cross IV, while it was moderate in cross I and cross III.

The narrow sense heritability of number of bolls /plant, seed cotton yield/plant and lint cotton yield/plant were of low values. Different results were obtained by El-Beially and Mohamed (2008). Concerning the heritability in $F_{3}$ as (b) of regression, indicated very low values of heritability in the four crosses, while the traits of lint percentage, micronaire value, fiber strength and fiber length exhibited high values in the four crosses. Boll weight was of moderate heritability value in the four crosses.

The expected genetic advance from selection of five percentage of better performance of the $F_{2}$ population for boll weight ranged from 0.29 in cross III to 2.29 in cross IV, while it was of negative value in cross II. The genetic advance of number 
of bolls /plant ranged from 8.11in crosses II to 43.31 in cross IV. Genetic advance of seed and lint cotton yield/plant ranged from 7.13 and 5.19 in cross I to 43.31 and 46.95 in cross IV. The range of genetic advance for lint percentage limited from 3.50 in cross II to 21 in cross IV. These results indicated that the main part of genetic effect in these crosses was nonadditive. At the same time, the high level of heterosis for number of bolls /plant, seed cotton yield/plant and lint cotton yield/plant and positive inbreeding depression for these traits suggested that the major part of genetic affect in these crosses were nonadditive.

The scaling tests of $C$ and $D$ to test non-allelic interaction together with five parameters, model and type of epistasis were given in (Table 4). The results in (Table 4) indicated the presence of non-allelic interaction for all traits in the four studied crosses, since one or both of $C$ and $D$ showed significance except the trait of number of bolls/plant in cross I which exhibited insignificant for the two tests of $C$ and $D$ indicating that the non-allelic interaction was absence in controlling the heritance for this trait.

These results may be taken as an evidence for failure of simple genetic model to certain genetic variation for these characters in the corresponding crosses. Therefore, the five parameters model was applied in order to assess the genetic interaction type controlling the genetic variation. The data in (Table 4) showed that the additive gene effects (d) were significant for all traits in the four crosses except for boll weight in the three crosses I,II, and III, lint percentage in cross III as well as fiber strength in cross I. These results were in harmony with those obtained by Khedr (2003). While dominance effects ( $h$ ) were significant for all traits in all crosses except for number of bolls/plant in crosses I and II as well as pressely index and fiber length in cross I. The results in Table (4) suggested that the dominance effects were greater in magnitude than additive effects for all traits in all crosses except fiber length in all crosses which exhibited greater magnitude for additive gene effect than dominance effect for fiber length. Regarding the epistatic component, Table (4) revealed that the component (i) additive $\mathrm{x}$ additive was positive and highly significant for seed cotton yield/plant and lint cotton yield/plant in the four crosses except in cross III in which the component (i) was negative and highly significant for seed cotton and lint cotton yield/plant. 
Table 4. Mother scales and genetic effects for eight studied characters in four Egyptian cotton crosses

\begin{tabular}{|c|c|c|c|c|c|c|}
\hline \multirow[b]{2}{*}{ Traits } & \multicolumn{2}{|c|}{ Mother scale } & \multicolumn{4}{|c|}{ Genetic effect } \\
\hline & C & D & d & $\mathbf{h}$ & $\mathbf{i}$ & $\mathrm{I}$ \\
\hline \multicolumn{7}{|c|}{ Cross I } \\
\hline B.W & $-1.71 \pm 0.11^{* *}$ & $-0.622 \pm 0.10^{* *}$ & $-0.002 \pm 0.02$ & $0.36 \pm 0.07 * *$ & $1.45 \pm 0.22 * *$ & $0.13 \pm 0.08$ \\
\hline No.Boll & $-11.08 \pm 8.08$ & $8.388 \pm 11.29$ & $2.36 \pm 0.87 * *$ & $11.80 \pm 7.98$ & $25.96 \pm 20.65$ & $-2.72 \pm 6.81$ \\
\hline S.C.Y & $8.39 \pm 11.29$ & $-140.114 \pm 24.88^{* * *}$ & $7.61 \pm 2.68 *$ & $62.15 \pm 23.56^{* *}$ & $173.50 \pm 61.55^{* *}$ & $-1.47 \pm 20.28$ \\
\hline L.C.Y & $-51.19 \pm 10.42^{* *}$ & $-11.156 \pm 13.09$ & $2.10 \pm 1.03^{*}$ & $35.31 \pm 9.39 * *$ & $53.38 \pm 25.12^{* *}$ & $3.10 \pm 8.17$ \\
\hline$L \%$ & $3.46 \pm 0.47 * *$ & $-4.101 \pm 0.69 * *$ & $0.53 \pm 0.06 * *$ & $5.62 \pm 0.48 * *$ & $-10.08 \pm 1.21^{* *}$ & $4.37 \pm 0.41^{* *}$ \\
\hline Mic & $-0.86 \pm 0.16^{* *}$ & $1.025 \pm 0.244^{* *}$ & $0.06 \pm 0.03 *$ & $-0.83 \pm 0.17 * *$ & $2.51 \pm 0.42 * *$ & $-0.71 \pm 0.15^{* *}$ \\
\hline F.S & $0.27 \pm 0.21$ & $0.416 \pm 0.191^{*}$ & $-0.002 \pm 0.02$ & $-0.23 \pm 0.15$ & $0.19 \pm 0.47$ & $-0.24 \pm 0.14$ \\
\hline F.L & $2.29 \pm 0.70^{* *}$ & $0.542 \pm 0.486$ & $0.22 \pm 0.06 * *$ & $0.02 \pm 0.41$ & $-2.33 \pm 1.45$ & $0.46 \pm 0.43$ \\
\hline \multicolumn{7}{|c|}{ Cross II } \\
\hline B.W & $-0.54 \pm 0.17^{* *}$ & $-0.84 \pm 0.18^{* *}$ & $-0.04 \pm 0.03$ & $0.44 \pm 0.13^{* *}$ & $-0.40 \pm 0.37$ & $0.39 \pm 0.13^{* *}$ \\
\hline No.Boll & $-38.27 \pm 9.36^{* *}$ & $-8.11 \pm 14.09$ & $2.51 \pm 0.88 * *$ & $16.55 \pm 9.91$ & $40.21 \pm 24.96$ & $4.06 \pm 8.20$ \\
\hline S.C.Y & $-159.14 \pm 27.32 *:$ & $-64.79 \pm 40.64$ & $5.95 \pm 2.49 * *$ & $70.00 \pm 28.64 * *$ & $125.80 \pm 72.57 * *$ & $28.57 \pm 23.78$ \\
\hline L.C.Y & $-66.18 \pm 10.61^{* * *}$ & $-40.43 \pm 15.43^{*}$ & $1.99 \pm 0.97 * *$ & $38.94 \pm 10.90^{* *}$ & $34.33 \pm 27.78$ & $19.90 \pm 9.09 * *$ \\
\hline$L \%$ & $-1.29 \pm 0.85$ & $-11.66 \pm 1.00^{* *}$ & $-0.22 \pm 0.06 * *$ & $8.50 \pm 0.73 * *$ & $-13.81 \pm 2.04 * *$ & $7.12 \pm 0.64 * *$ \\
\hline Mic & $-0.27 \pm 0.15$ & $2.70 \pm 0.22^{* *}$ & $0.11 \pm 0.03 * *$ & $-1.85 \pm 0.15 * *$ & $3.96 \pm 0.38 * *$ & $-1.63 \pm 0.14 * *$ \\
\hline F.S & $-0.71 \pm 0.13^{* *}$ & $-0.86 \pm 0.21^{* *}$ & $0.11 \pm 0.02 * *$ & $0.46 \pm 0.15^{* *}$ & $-0.20 \pm 0.36$ & $0.68 \pm 0.12^{* *}$ \\
\hline F.L & $-2.40 \pm 0.41^{* *}$ & $1.37 \pm 0.48^{*}$ & $0.61 \pm 0.07 * *$ & $-1.31 \pm 0.34 * *$ & $5.03 \pm 0.93 * *$ & $-0.09 \pm 0.33$ \\
\hline \multicolumn{7}{|c|}{ Cross III } \\
\hline B.W & $0.33 \pm 0.14^{*}$ & $-0.77 \pm 0.11^{* * *}$ & $0.01 \pm 0.02$ & $0.57 \pm 0.08 * *$ & $-1.47 \pm 0.25 * *$ & $0.58 \pm 0.09 * *$ \\
\hline No.Boll & $22.84 \pm 11.31^{*}$ & $0.64 \pm 10.10$ & $6.40 \pm 0.93 * *$ & $51.11 \pm 7.75^{* *}$ & $-29.60 \pm 24.00$ & $16.19 \pm 7.43^{* *}$ \\
\hline S.C.Y & $101.42 \pm 37.29^{* *}$ & $-58.36 \pm 30.91$ & $21.13 \pm 2.92 * *$ & $209.66 \pm 24.32 * *$ & $-213.04 \pm 77.69 * *$ & $98.07 \pm 23.83 * *$ \\
\hline L.C.Y & $28.57 \pm 14.67^{*}$ & $-32.89 \pm 12.07 *=$ & $8.62 \pm 1.17 * *$ & $94.47 \pm 9.51 * *$ & $-81.94 \pm 30.37 * *$ & $43.94 \pm 9.33^{* *}$ \\
\hline$L \%$ & $-2.95 \pm 0.64^{* *}$ & $-4.79 \pm 0.64^{* *}$ & $0.13 \pm 0.07$ & $4.77 \pm 0.48 * *$ & $-2.45 \pm 1.40$ & $2.96 \pm 0.45 * *$ \\
\hline Mic & $0.059 \pm 0.12$ & $-0.832 \pm 0.14^{* *}$ & $0.13 \pm 0.02 * *$ & $0.56 \pm 0.10^{* *}$ & $-1.18 \pm 0.27 * *$ & $0.82 \pm 0.10^{* *}$ \\
\hline F.S & $-0.32 \pm 0.11^{* *}$ & $0.10 \pm 0.15^{* *}$ & $0.04 \pm 0.02 * *$ & $-0.72 \pm 0.11 * *$ & $1.76 \pm 0.28 * *$ & $-0.64 \pm 0.10 * *$ \\
\hline F.L & $1.16 \pm 0.20^{* * *}$ & $0.42 \pm 0.27$ & $0.63 \pm 0.05 * *$ & $-0.08 \pm 0.18$ & $-0.99 \pm 0.45 * *$ & $1.17 \pm 0.18^{* *}$ \\
\hline \multicolumn{7}{|c|}{ Cross IV } \\
\hline B.W & $-0.21 \pm 0.10^{*}$ & $1.64 \pm 0.08 * *$ & $0.14 \pm 0.01 * *$ & $-0.94 \pm 0.06 * *$ & $2.47 \pm 0.19 * *$ & $-0.84 \pm 0.06 * *$ \\
\hline No.Boll & $-87.71 \pm 6.60 * *$ & $-88.02 \pm 7.64 * *$ & $15.82 \pm 0.83 * *$ & $75.81 \pm 5.50 * *$ & $-0.41 \pm 15.26$ & $75.71 \pm 5.059 * *$ \\
\hline S.C.Y & $-305.83 \pm 21.65 * *$ & $-202.55 \pm 24.75$ & $58.77 \pm 2.64 * *$ & $198.18 \pm 17.83 * *$ & $137.71 \pm 49.06 * *$ & $201.60 \pm 16.27^{* *}$ \\
\hline L.C.Y & $-126.65 \pm 7.89 * *$ & $-66.61 \pm 9.71 * *$ & $26.68 \pm 1.05 * *$ & $67.16 \pm 6.92 * *$ & $75.44 \pm 18.49 * *$ & $77.80 \pm 6.23 * *$ \\
\hline$L \%$ & $2.71 \pm 0.55 * *$ & $5.31 \pm 0.68 * *$ & $1.96 \pm 0.07 * *$ & $-5.01 \pm 0.56 * *$ & $12.30 \pm 1.73 * *$ & $-1.19 \pm 0.54 * *$ \\
\hline Mic & $-0.82 \pm 0.14 * *$ & $2.56 \pm 0.17 * *$ & $0.17 \pm 0.03 * *$ & $-1.84 \pm 0.12 * *$ & $4.50 \pm 0.32 * *$ & $-1.51 \pm 0.12^{* *}$ \\
\hline F.S & $0.30 \pm 0.08 * *$ & $1.90 \pm 0.11^{* *}$ & $0.10 \pm 0.02 * *$ & $-1.21 \pm 0.07 * *$ & $2.14 \pm 0.18^{* *}$ & $-1.02 \pm 0.07 * *$ \\
\hline F.L & $-1.75 \pm 0.24 * *$ & $2.37 \pm 0.32 * *$ & $1.06 \pm 0.05 * *$ & $-1.87 \pm 0.22 * *$ & $5.49 \pm 0.56^{* *}$ & $0.24 \pm 0.21$ \\
\hline
\end{tabular}

$\mathrm{d}=$ additive, $\mathrm{h}=$ dominance, $\mathrm{i}=$ additive $\mathrm{x}$ additive, $\mathrm{I}=$ dominance $\mathrm{x}$ dominance

The lint percentage exhibiting negative and highly significant epistatic component (i) in the two crosses I and II, while was positive and highly significant in cross IV.

The epistatic component (i) was insignificant for number of bolls/plant in the four crosses, while boll weight was positive and highly significant in cross I and cross 
IV. On the other hand, the component (i) was negative, and highly significant in cross III.

Positive and highly significant (additive $\mathrm{x}$ additive) epistatic effects were obtained for Micronaire values in the four crosses except cross III, pressely index in the two crosses (III and IV), and fiber length in two crosses (II and IV), while the same epistatic effects negative and highly significant in crosses (III and IV). From these results complementary epistasis were noticed as revealed by no differences in sign of $\mathrm{d}$ and (I) in crosses, which exhibited significant epistatic effects in most characters. Bhatti et al., (2006)

On the other hand, table (4) revealed that (dominance $x$ dominance) epistatic effects were insignificant ( in cross I ) for all studied characters except for lint\% which was positively significant and Micronaire values (negatively significant). Meanwhile, in crosses II , III and IV those epstatic effects were highly significant for traits for number of bolls/plant (in cross II) and fiber length (in the two crosses II and IV). Complementary epistasis was noticed as revealed by no differences in sign between $\mathrm{h}$ and I in most traits.

\section{CONCLUSION}

The differences between the parental lines for seed cotton yield and lint cotton yield were highly significant, this observation plus the relatively high level of heterosis, the presence over of dominance and significant inbreeding depression verified by significant non additive dominance component and complementary action of component epastasis of dominance $\mathrm{x}$ dominance as well as little magnitude for additive component with this material suggested that for improving these traits effective breeding method and severe selection must be used to produce desirable strains.

\section{REFERENCES}

1. Abdalla, A.M.A., 2007. Inter and intraspecific cotton crosses 1- Heterosis performance and generations correlation targeted growth, earliness and yield variables of $F_{1}$ and $F_{2}$. Egypt. J. Plant Breed. 11(2): 793 - 811.

2. Abd-El-Haleem, S.H.M.; E.M.R. Metwali and A.M.M. Al-Felaly, 2010. Genetic analysis of yield and its components of some Egyptian cotton (Gossypium barbadense L.) varieties. World J. Agric. Sci., 6 (5): 615-621.

3. Abou El-Yazied, M.A.; A. M. Abd El-Bary and M.M. Allam. 2008. Genetic studies of some quantitative traits in two cotton crosses (Gossypium barbadense L.). Egypt. J. of Agric. Res., 86(4) 1463- 1475. 
4. Allard, R.W. 1960. Principles of plant breeding. John Willey and Sons, Inc., New York.

5. Bhatti, M.A.; F.M. Azhar and A.W. Alvi, 2006. Estimation of additive, dominance and epistatic components of geneic variation in fiber quality characters of upland cotton grown in salinized conditions. Int. j. agric Bio. Vol. 8, (6): 824- 827.

6. El-Beially, I.E. and G.I.A Mohamed, 2008. Estimates of genetic parameters using six populations in Egyptian cotton (Gossypium barbadense L.). Al- Azhar J. Agric. Res., 4: 51- 64.

7. El-Disouqi, A.E. and A.M. Ziena, 2001. Estimates of some genetic parameters and gene action for yield and yield components in cotton. J. Agric. Sci., 126: 34013409.

8. El-Disouqi, A.E.; Z.F. Abo-Sen and A.R.Abo-Arab 2000. Genetic behavior of yield and its components in Egyptian cotton. J.Agric . Sci. Mansoura Univ., 25(7) : 3831-3840

9. El-Hoseiny H. A.; M.H. M. Orabi and K.M.A. Baker 2013. Genetical analysis of some yield components and fiber quality of two hybrids cotton. Plant Production, Mansoura Univ., Vol. 4 (5): 861 - 87.

10. Jinkes, J.L. and R.M. Jones (1958). Estimation of the components of heterosis. Genetics 43: 223 - 234.

11. Johanson, H.W., H.F. Robinson and R.E. Comostock, 1955. Etimates of genetic and environmental variability in Soybean. Agron. J. 47: 314-318

12. Khedr, A. H., 2003. Genetical studies on cotton. Ph.D. thesies, Fac. Agric. Zagazig Univ. Egypt.

13. Mather, K. and J.L. Jinks, 1982. Biometrical Genetics. 3 Ed. Chapman and Hall, London, pp: 396.

14. Petr, F.C. and K.J. Frey, 1966.Genotypic correlation, dominance and heritability of quantitative characters. Oats Crop sci., 6:259-262.

15. Smith, H.H.1952. Fixing transgressive vigour in nicotine.Heterosis . Iowa State College Press, Ames.Iowa, UAS

16. Soliman, Y, A.M. 2003. Studieson some quantitative characters in some intraspecific cotton crosses. Ph.D. Thesis, Fac. of Agric. Kafr El-Sheikh, Tanta Univ., Egypt.

17. Zeina , A.M.A. 2002. Using biparental mating system to produce new promising recombination in cotton. Egypt . J. Agric.,Res.,80(1):325-340. 
السلوك الو راثي لصفات المحصول و الجودة في بعض هجن القطن الباربادنس مصطفي حسني محمد عرابي ، ايمان محمد ربيع محمد صالح ، سامية البرل سبد علي

$$
\text { معز بحوث القطن - مركز البحوث الزراعية - الجيزة - مصر }
$$

اجري هذا البحث بمحطة البحوث الزراعية بسخا محافظة كفر الثيخ خلال اربعة مواسم

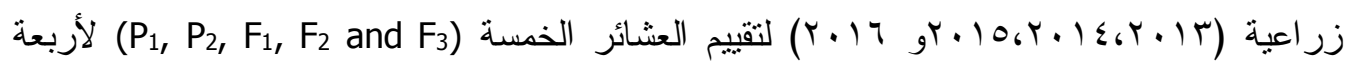

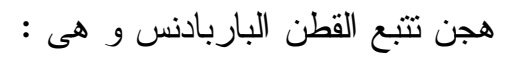
(BBB x C.B 58 ) ، ( TNB x C.B 58 ) ، ( Uzbekstan1 x C.B 58)

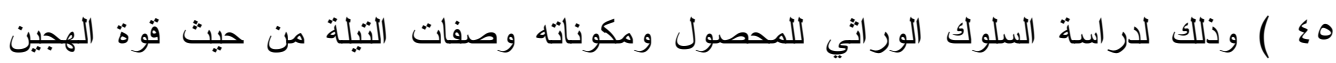

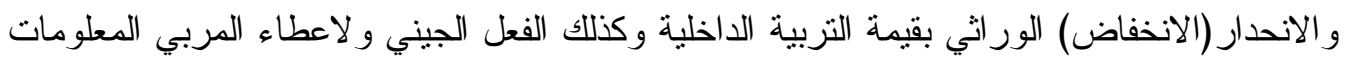

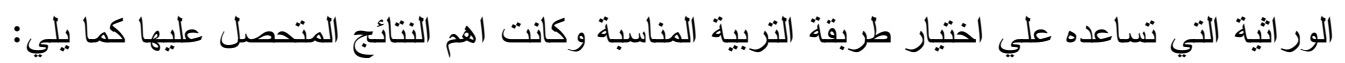

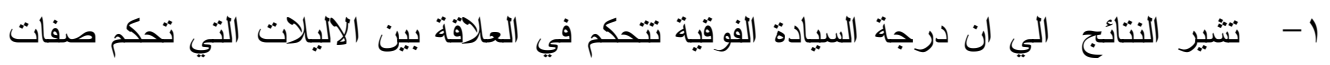

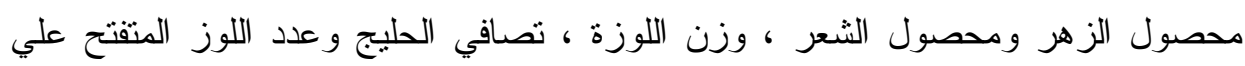

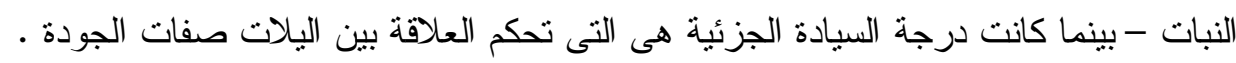

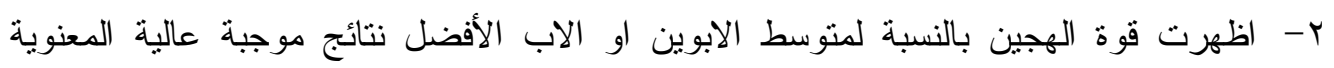

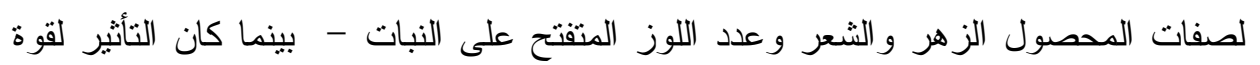

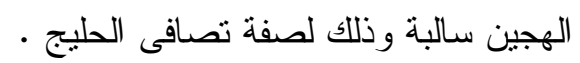
r- كان الانخفاض الور اثى نتيجة النربية الداخلية عالى المعنوية لصفات المحصول الزهر والثعر و عدد اللوز المتقتح على النبات.

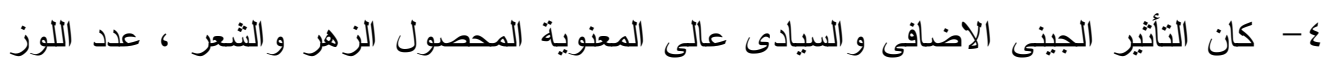

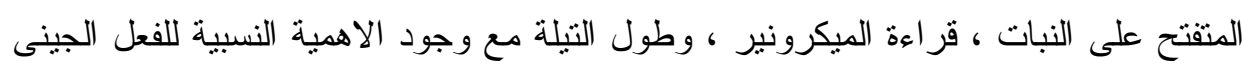

$$
\text { السيادى على الفعلى الاضافى. }
$$

0- كان التفوق من النوع الاضافى × الاضافى ، الاضئى السيادى × السيادى عالى المعنوية مع وجود التكامل بينه وبين الثأثير الغير اضافى.

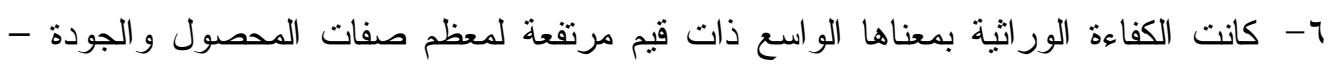

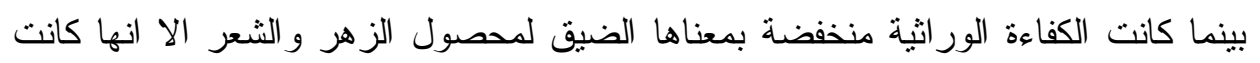

$$
\begin{aligned}
& \text { عالية لصفات الجودة فى الهجين الثانى و الثالث و الرابع. } \\
& \text { - - - كانت الكفاءة الور اثثة فى الجيل الثالث مرتفعة. }
\end{aligned}
$$

